\title{
Visit to the Falklands
}

In January the Hon. Secretary and Hon. Editor, at the request of FPS Council, spent a fortnight in the Falkland Islands, part of the time as guests of the Governor, HE J. R. W. Parker and Mrs Parker, to negotiate on the future of New Island with a view to preserving both the island's habitat and its superb wildlife. Also in the party were Mr Michael Wright, General Counsel of the US Nature Conservancy, and Marcus Stauffacher, a zoologist from Basel University who represented a group of Swiss conservationists with a special interest in New Island. The party benefited greatly from the presence in the islands for four days of the Society's Chairman, Sir Peter Scott, on board the Lindblad Explorer. We succeeded in negotiating two very satisfactory agreements, although pending legal consultations, it is not possible yet to make a full statement on the details. The two main achievements which can be announced were the decision to set up a trust to be called the Falkland Islands Foundation, with the full approval of the Governor and many residents, and an agreement for the management of the southern half of New Island in the immediate future, including the control of rabbits and the fencing of tussac grass areas so that sheep can only enter them at the right times of year.

New Island, one of the most westerly of the archipelago, is the most important wildlife island in the Falklands, having substantial colonies of fur seals, southern sealions, black-browed albatrosses, rockhopper, gentoo and Magellan penguins, and thin-billed prions. Two endangered birds, the ruddyheaded goose and the striated caracara or Johnny rook, also breed there. The terrestrial habitats have been severely maltreated through burning and overgrazing by sealers and sheep farmers, over the past century and a half, and the introduction of rabbits. Comparatively little of the native tussac grass, so important for breeding seabirds, remains, and the most urgent management problems relate to the fencing of the tussac areas against sheep. Yorkshire fog grass, introduced as sheep feed, covers large areas and poses special problems.

The FPS has been concerned with New Island since 1971, when $\mathrm{Mr}$ Ian Strange approached the Society for help in acquiring it as a nature reserve. In the event Ian Strange and $\mathrm{Mr}$ W. R. Napier, another Falkland farmer, have divided the island: Strange owns the southern half, Napier the northern. Both aim to conserve the wildlife and prove that this is compatible with both sheep farming and tourism. The purchase was partly financed by the sale of seven small off islands to the Society for the Promotion of Nature Reserves, which already owned two small Falkland Islands, the Twins, some 30-40 miles north of New Island. FPS was active in promoting this transaction and advises the SPNC on their management. We were able to land on two of these during our visit.

The total population of the Falklands is now only about 1800 , of whom half live in Stanley, the only town. In the 'camp' as everything outside Stanley is called, the only communication is by radio telephone. Transport is exceedingly difficult: there are no roads outside Stanley, and contact with the camp is maintained by two 5-seater Beaver seaplanes. The islanders' sole economic interest is in sheep farming, and the creation of reserves and sanctuaries is liable to be suspect, because of the fears that sheep will be prevented from grazing on them. But there are signs that sheep ranching is in effect mining the nutrients out of the soil and leading to a widespread degradation of the terrestrial ecosystems. These ecosystems are, however, now for the most part so man- 


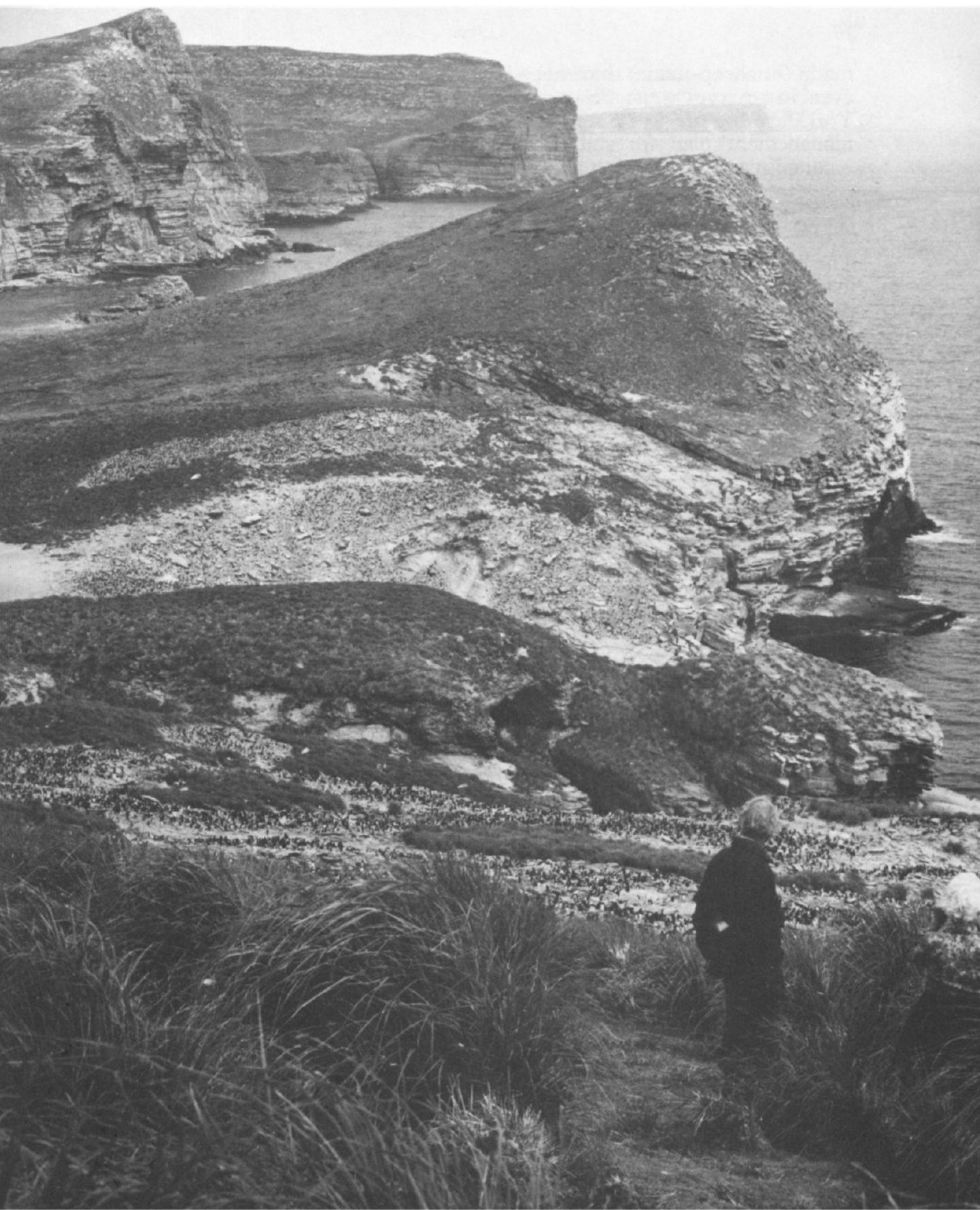

NEW ISLAND with rockhopper penguin rookery in the middle ground and tussac grass in the foreground Ian Strange 
made (or sheep-made) that sheep have become an essential part of them, and even in reserves must be used, if, for instance, introduced grasses such as Yorkshire fog are to be kept under control. It is hoped that the agreed new management plan for southern New Island will be a first step towards reconciling sheep farming and wildlife conservation.

\section{Arid Ecosystems}

R. S. R. FITTER

The best reason for holding a workshop on the management of arid ecosystems in Cairo last November was that hardly anywhere in the world could any of the participants cite any instances of arid ecosystems being actually managed. Examples of the mistreatment are galore. Cairo itself stands in the middle of one of the largest arid ecosystems in the world, stretching from the coast of Morocco through Arabia to the Gobi Desert. The history of human civilisation, especially in its earlier millennia, is largely the history of the destruction of once fertile lands-part of the Middle East was once called the Fertile Crescent-and North Africa, now largely desert, was once the granary of Rome, the resource base of the world's first great international empire. The modern world shows little sign of heeding the lessons of the past. Despite the UN Desertification Conference in Nairobi last year, which produced many sound recommendations, the conservation of the remaining fertility of the world's arid regions still commands as little priority as any other enterprise that does not show an immediate profit on the balance sheet.

The Cairo Workshop, jointly sponsored by the Egyptian Academy of Scientific Research Technology and the US Department of the Interior, marked a first small step towards sanity. But the Sahara desert continues to advance southwards much faster than governments are taking effective action to check it. Sahel countries had good rains this year, so politicians at once think that after all it is not so urgent to do the inconvenient things they must do if the desert is not to spread. The Arabian oryx, now probably extinct, and the addax and scimitar-horned oryx, now well on the way to extinction, are the animals designed by nature to graze the arid lands, and were once numerous enough to be domesticated in ancient Egypt. Their successors brought by man, the cow, the sheep and the goat, have been the main instruments of the destruction of the fertility of those arid lands. Perhaps there is sc-nething in wildlife conservation after all?

\section{Natural Areas on World Heritage List}

The first 12 areas to be selected for the World Heritage list include four Natural Heritage Areas: Nahanni National Park, Canada; Galapagos Islands, Ecuador; Simien National Park, Ethiopia; and Yellowstone National Park, USA. Nahanni, a vast almost untouched wilderness of 1850 square miles in north-west Canada which includes the Mackenzie Mountains, covers habitats ranging from alpine tundra to subalpine and boreal forests and harbours Dall sheep, mountain goat, grizzly bear, grey wolf, caribou, peregrine falcon, golden and bald eagles and trumpeter swan; the Galapagos in the Pacific, with their extraordinary tally of endemic plants and animals, were an obvious choice; Simien, $165 \mathrm{sq} \mathrm{km}$ of spectacular mountain scenery on the north ledge of the Ethiopian plateau, harbours the rare walia ibex, Simien fox and gelada baboon; Yellowstone, $100,000 \mathrm{ha}$, with spectacular scenery, geysers, and the largest caldera on earth, harbours endangered and threatened species, including grizzly bear, mountain lion (cougar), Artic grayling, bald eagle and trumpeter swan as well as mule deer, elk, moose, bison, black bear, coyote and pronghorn. 